\title{
Foveal hypoplasia-presenile cataract syndrome
}

INSERM

\section{Source}

INSERM. (1999). Orphanet: an online rare disease and orphan drug data base. Foveal hypoplasia-presenile cataract syndrome. ORPHA:2253

Foveal hypoplasia-presenile cataract syndrome is a rare, genetic ocular disease characterized by cong enital nystagmus (horizontal, vertical and/or torsional), foveal hypoplasia, presenile cataracts (with typical onset in the second to third decade of life), and normal irides. Corneal pannus and/or optic nerve hypoplasia may also be present. 